\title{
An Assessment of the Role of Credit Reference Bureau in Influencing Risk Identification in Mitigating Credit Default in Commercial Banks in Kenya
}

\author{
Ruthwinnie Njeri Munene ${ }^{\# 1}$, Prof.Tom Nyamache ${ }^{\# 2}$,Dr. Paul Muoki Nzioki \#3 \\ P.O BOX Private Bag Kabarak
}

\section{ABSTRACT}

The study examined the role of Credit Reference Bureau (CRB) in influencing risk identification in militating against credit default in commercial banks in Kenya. The study used a CausalComparative descriptive survey design in evaluating the role of CRB in influencing risk identification in mitigating against credit default in commercial banks in Kenya. The target population of the study consisted of all the 43 licensed commercial banks in Kenya and the three licensed credit reference bureaus in Kenya under the Banking Act. The researcher used census method commercial bank headquarters bank managers and the three headquarters credit reference bureau managers. Primary data was collected using questionnaires. Secondary data were collected from CBK loan books and CBK annual Bank supervisory reports. Data was analyzed using SPSS and results presented using graphs. The researcher used descriptive statistics and inferential statistics. Inferential statistical tests used comprised of correlation, ANOVA regression and Chi-square analysis to test hypothesis. $\mathrm{P}$-value yielded was less than 0.05, which indicated that the roles played by CRB in influencing risk identification have significant influences on the Credit Default Rate in commercial banks in Kenya. The conclusion was that CRB plays a significant role in risk identification.

Key words: Credit Reference Bureau, credit default, risk identification and commercial banks

Corresponding Author: Ruthwinnie Njeri Munene

\section{INTRODUCTION}

The emergence of CRBs has significantly revolutionized lending and contributed to the improved financial performance of many financial institutions in Kenya. Before the introduction of CRB, many borrowers used to borrow from one institution to the other without being identified. This led to many financial institutions experiencing immense losses because of NPLs.(Berger \& Frame,2005). Through the use of CRB, the banks are in a position to obtain detailed information on a person's credit history, including information on their identity, credit accounts and loans, bankruptcies and late payments and recent inquiries. Other information shared include: proven frauds and forgeries, cheque kiting, false declarations and statements, receiverships, bankruptcies and liquidations, credit default and late payments, use of false securities and misapplication of borrowed funds (CBK, 2009). According to Brown and Marco (2007) CRBs are information brokers, providing creditors with reliable, relevant and comprehensive data on the repayment habits and current debt of their credit applicants. Under 
reciprocity agreements, credit bureaus obtain data from creditors and other sources, consolidate and package information into individual reports, and distribute it to creditors for a fee. Lewis (2004) indicates that most financial institutions and most creditors prefer hard collateral-based credit but would extend cash flow-based credits if they can use a reliable and inexpensive system to exchange information on the character and ability to pay of borrowers. The need for establishment of CRB services in any financial system arises because of information asymmetry between lenders and borrowers when financial institutions compete with each other for customers, multiple borrowing and over-indebtedness increases loan default unless the financial institutions have access to databases that capture relevant aspects of clients' borrowing behavior. The CRB contributes significantly to reduction in the costs of screening loan applications by enabling the lender to sort out prospective borrowers who have defaulted with other lenders (Mwisho, 2001).

\subsection{Statement of the problem}

According Ahmad (2007) however despite the roll out of CRB in Kenya and their facilitation of data sharing, there is still an increase in credit risk. Kenyan banking sector was saddled with a momentous NPLs portfolio which is a critical source of economic distortion and stagnation which must not only be monitored but also controlled. This invariably led to the collapse of some banks. CBK in the year 2015 placed Dubai Bank of Kenya owing to the deteriorating cash reserve ratio position and failure to honor financial obligations, including kshs 48 million due to Bank of Africa Kenya. Chase Bank in the same year had made a loss of kshs 742 million, despite making a profit of kshs 2.3 billion the previous year. The loss was attributed to bad and insider loans totaling to kshs 16.6 billion. National Bank of Kenya in the year 2015 reported kshs 1.2 billion loss compared with a profit of kshs 1.3 billion in the same period in 2014. The huge loss was blamed on the issued bad loans. Imperial Bank Ltd in 2016 under receivership for facing serious liquidity problems. One of the catalysts were "Serial defaulters" who borrowed from various banks with no intention of repaying the loans.(CBK 2016).In the Kenyan Milieu, few aspects relating to Credit Reference Bureau have been reviewed Al-Khouri (2011). Sigei (2010) evaluated the effectiveness of CRB in Kenya, Ng'anga (2011) investigated stakeholder perception of credit reference bureau services in the Kenyan credit market, Gaitho (2010) studied the role of credit reference bureau on credit access, and Mumi (2010) appraised the impact of credit reference bureau in financial institutions in Kenya; Therefore, this study aims to determine the role of CRBs in influencing credit risk identification in mitigating against loan default in Commercial banks in Kenya.

\subsection{Objective of the study}

To establish the role of CRB in influencing credit risk identification in mitigating against credit default in commercial banks in Kenya.

\subsection{Research hypothesis}

H01: CRB does not play a significant role in influencing risk identification in mitigating against credit default in commercial banks in Kenya.

HA $_{1}$ : CRB plays a significant role in influencing risk identification in mitigating against credit default in commercial banks in Kenya. 


\section{LITERATURE REVIEW}

\subsection{Theoretical Review}

Moral hazard theory: According to Pagano and Japelli (1993) moral hazard refers to the risk in which a party to a transaction provides misleading information about its assets, liabilities or credit capacity, or has an incentive to take unusual risks in a desperate attempt to earn a profit before the contract settles Usually a party to a transaction may not enter into the contract in good faith, thus providing misleading information about its assets, liabilities or credit capacity. Problems of moral hazard in financial institutions are evident at many stages of the recent financial crises. This theory is considered relevant in this study since borrowers and lenders tend to conceal crucial information pertaining to the lending and borrowing agreement. Yet in modern macroeconomic theory, economic growth rate depends, crucially, on the efficiency of financial institutions. The financial systems themselves depend on accurate information about borrowers and the project the funds are used for.According to Alary and Goller (2001) credit bureaus improve banks knowledge about applicant's characteristics and permit more accurate prediction of repayment probability. This allows lenders to target and price their loans better, easing adverse selection problems. In this respect, the benefit of establishing a credit bureau is greatest where a large number of customers on which it has no previous information that is where borrowers are very mobile confront each bank. Credit bureaus reduce the informational rents that banks could otherwise extract from their customers. They tend to level the informational playing field within the credit market and force lenders to price loans more competitively. Lower interest rates increase borrower's net return and augment their incentive to perform. Credit bureaus work as a borrower discipline device where every borrower knows that if he defaults his reputation with all other potential lenders is ruined, cutting him off from credit or making it much more expensive. This mechanism also heightens borrower's incentive to repay, reducing moral hazard. Adverse Selection Theory: According to Stieglitz \& Weiss (1981) originated the concept of adverse selection. The theory rests on two main assumptions, which lenders cannot distinguish between borrowers of different degrees of risk, and that loan contacts are limited. This analysis is restricted to involuntary default, that it assumes that borrowers repay loans when they have the means to do so. In a world with simple debt contacts between risk-neutral borrowers and lenders, the presence of limited liability of borrowers imparts a preference for risk among borrowers, and a corresponding aversion to risk among lenders. This is because limited liability of borrowers implies that lenders bear all the downside risk. On the other hand, all returns above the loan repayment obligation accrue to borrowers. Raising interest rates would affect the profitability of low risk borrowers disproportionately, causing them to drop out of the application pool. However, excess demand in the credit market may persist even in the face of competition and flexible interest rates. In the adverse selection theory, the interest rate may not raise enough to guarantee that all loan applicants secure credit, in times when loanable funds are limited. In general, borrowers who have greater wealth to put as collateral obtain cheaper credit and have incentives to work harder, and earn more income as a result. Existing asset inequalities within the borrowing class are projected and possibly magnified into the future by operation of the credit market, a phenomenon that may cause the persistence of poverty. By exchange information about their customers, banks can improve their knowledge of applicants' characteristics and behavior. In principle, this reduction of informational asymmetries can reduce adverse selection problems in the lending, as well as change borrowers' incentives to repay. According to Brown and Marco (2007) they argued that information sharing reduces adverse selection by improving banks information on credit applicants. The theory of asymmetric 
information explains that it may be difficult to distinguish good borrowers from bad borrowers, which may result into adverse selection and moral hazards problems. The theory explains that in the market, the party that possesses more information on a specific item to be transacted in this case the borrower is in a position to negotiate optimal terms for the transaction than the other party in this case, the lender. The party that knows less about the same specific item to be transacted is therefore in a position of making either right or wrong decision concerning the transaction. Adverse selection and moral hazards have led to significant accumulation of nonperforming loans in banks.

\subsection{Empirical review}

According to Kargi ( 2011) the creation of credit reference bureau is one of the most effective means to reducing non-performing loans in the economy. The introduction of CRB in the financial landscape is an effort to encourage sharing of information by institutions so as to reduce the incidence of serial defaults by bank customers as well as minimize the incidences of nonperforming loans. The introduction of CRB help players in the sector to start building their capacity to borrow from sector since the credit information sharing allows the banks to distinguish between good and bad borrowers. The CRB are meant to complement the central role played by banks and other financial institutions in extending financial services within an economy. Risk identification is vital for effective risk management. With the presence of a CRB, there is strong motivation for clients to repay their loans leading to improved financial performance (Bessis, 2003).

CRBs help make faster and accurate credit decisions. They collect, manage and disseminate customer information to lenders within a regulatory framework. Credit histories not only provide necessary input for credit underwriting but also allow borrowers to take their credit history from one financial institution to other thereby making lending markets more competitive and in the end more affordable. Credit bureau assist in making credit access to more people and enabling lenders and business reduce risk and fraud. These risks typically increase the price of credit in the economy. Sharing information between financial institutions in respect to customer credit behavior therefore has a positive economic impact. Banks play a central role in extending financial services within an economy. In support of this role credit bureau help lenders make faster and more accurate credit decisions ( Jappeli, 2002).

The Credit Bureaus are meant to deal with moral hazard and adverse selection problem through monitoring the behavior of borrowers. The operations of credit reference bureau should be underpinned by strong legal framework so as to be better able to deal with adverse selection and moral hazard problems to reduce risk and fraud (Masetti, 2006). Adverse selection is the problem created by asymmetric information before a transaction occurs, whilst adverse selection in financial market occurs when those potential buyers who are most likely to produce an undesirable outcome the bad credit risk are the ones actively seek out credit are the most likely to be selected. Moral hazard created by asymmetric information after a transaction occurs. Moral hazard in financial market occurs when the lender is subjected to the hazard that the borrower has incentives to engage in activities that are undesirable from the lenders point of view, because those activities make it less likely that the loan will be repaid back. (Bruce, 2007) 


\section{MATERIALS AND METHODS}

\subsection{Research Design and target population}

The study used a Causal-Comparative descriptive survey design in evaluating role of CRB in influencing risk identification on mitigating loan default among commercial banks in Kenya. This was used because it gives a systematic collection and analysis of data in order to answer questions concerning current status of CRB the way it is without changing the environment Mugenda \& Mugenda (2003). Causal-comparative studies attempt to identify cause effect relationships, involve comparison, and attempts to make inferences without direct intervention. This design was appropriate for this study because comparison allowed for the establishment of conclusive causality attributing observed changes in effectiveness of CRB practices. The study was carried out at the commercial bank headquarters and credit reference bureau headquarters in Nairobi County. The population of the study consisted all the licensed commercial banks in Kenya and the CRBs under the Banking Act. According to the CBK, there were 43 licensed banks and three CRBs in Kenya as at $31^{\text {st }}$ march 2015 CBK (2012). All these banks were studied since a conclusive and completely representative analysis was to be arrived at in the end.

\subsection{Sample size and Sampling Procedures}

The researcher used judgment sampling technique that is a non-probability method. The selected sample was based on judgment. The researcher drew the entire sample from the population using census approach. The researcher was confident that the chosen sample was truly representative of the entire population. All credit commercial bank managers at the headquarters and credit reference bureau managers were used for the study.

Table 1: Respondent's Categories Sample Size

\begin{tabular}{ll}
\hline Respondent's Categories & Respondents Size \\
\hline Bank Credit managers & 41 \\
Credit Reference Bureau Africa Limited (TransUnion) managers & 1 \\
Metropol Credit Reference Bureau Ltd managers & 1 \\
\hline Total & $\mathbf{4 3}$ \\
\hline
\end{tabular}

\subsection{Research Instrument and piloting}

To collect primary data, the researcher used questionnaires. Questionnaires gave the respondents room for airing well thought information adequate to base good judgment. Besides secondary data required for this study were collected from CBK loan book, CBK annual Bank supervisory reports. The data required was collected for a period five years, before the introduction of CRB and five years after to show the trend of loan defaults before and after the introduction of CRBs. Other sources of secondary data included annual publications, newspapers, journals, monthly publication, and library books were used to form the backbone of literature review. According (Orodho, 2003), a pilot study is necessary for testing the reliability of data collection instruments. Validity is concerned with the question of whether an instrument measures what it intends to measure (Nachmias \& Nachmias1996). To ensure validity, questionnaire were prepared in conjunction with literature review and based on the research objectives and questions. The questionnaire was discussed with the supervisor, colleagues, experienced researchers and professional bankers. Completed questionnaires were collected directly from respondents that enabled any clarification of any issues. Reliability is the degree to which an 
instrument measures accurately what it claims to measure. According to Powell, (2004) reliability is always contingent on the degree of uniformity of the given characteristics in the population. This implies that the more heterogeneous the population is concerning the variable in question, the more reliable the instrument is likely to be. In assessing reliability of the data, internal consistency method using Cronbach's alpha was used.

\subsection{Data Collection analysis and presentation}

With the help of research assistants, the researcher visited the commercial banks and CRBs and administered the questionnaires. Arrangements were made with the assistance of public relations officers to administer questionnaires to the credit managers and CRB management at the headquarters. The researcher acquired a research permit from National Council of Science and Technology (NCST). The researcher also had an introduction letter from Kabarak University. The researcher then administered the questionnaires to the respondents. The researcher to keep the date for the study used an electronic spreadsheet. The researcher sent an email to the respondents in advance explaining the purpose of the study. The questionnaires were delivered to the target respondent by the researcher and research assistant to allow familiarity with the respondent in building the confidence between the researcher and the respondent on the intention of carrying out the study. The questionnaires were picked after two weeks from the date of issuance when a prearranged date was confirmed for collection. On completion, the researcher organized the data received, coded, edited and tabulated to check accuracy, completeness and storing it in appropriate form. The data was stored in electronic form and paper form for the purpose of data analysis. The data was analyzed using spreadsheet as it has versatile analysis and storage combination tools. Spreadsheet incorporated elements of exploratory data analysis and relevant information from the spreadsheet was copied directly across to a report. The data was presented using graphical systems, which included histograms and pie charts, frequency distributions tables and numerical methods. The data was analyzed in order to make deductions and inferences. Exploratory method was used to analyze qualitative research and confirmatory method was used to analyze quantitative research. Statistical techniques were also used to analyze the data, which measured measures of central tendency that is the mean, the median and the mode. Measures of dispersion were also calculated which included standard deviation. Statistical computing was done using Excel and Statistical Package for Social Sciences (SPSS). The researcher maintained integrity in the application of the statistical skills without concern for a favoured outcome. The researcher justified the research via an analysis of the balance of cost that there has to be benefits from the study that outweigh the cost. The researcher maintained confidentiality at all times, was responsible for the work and for the contribution to the whole study. The researcher obtained informed consent from any subject used in the study and ensured that all subjects participated voluntarily. The researcher was open and honest in dealing with the respondents and fully explained the research in advance and debriefed respondents afterwards.

\section{RESULTS AND DISCUSSION}

\subsection{Pilot study and response rate}

The researcher conducted a pilot study in two banks that are homogeneous in terms of composition and operations with the targeted banks to establish the reliability of the research tools. The results are presented in Table 2 
Table 2. Reliability Analysis

\begin{tabular}{lcc}
\hline Reliability Statistics & No. of Items & Cronbach's Alpha value \\
\hline Credit risk identification & 14 & 0.756 \\
\hline Credit default rates in commercial banks & 15 & 0.729 \\
\hline
\end{tabular}

A coefficient of above 0.7 was obtained and this indicated that the data collection instruments were valid (Kothari, 2005). Data validity played an important role towards generalization of the gathered data to reflect the true characteristics of the study problem. An alpha coefficient higher than 0.7 indicates that the gathered data has a relatively high internal consistency and could be generalized to reflect opinions of all respondents in the target population (Mandrish and Schaffer, 2005).

Table 3. Response Rate

\begin{tabular}{lcccc}
\hline $\begin{array}{l}\text { Response } \\
\text { Frequency }\end{array}$ & Category & Response & Frequency & $\begin{array}{l}\text { Non- } \\
\text { Response }\end{array}$ \\
\hline Unit response & 35 & 81.39 & 8 & 18.61 \\
Item response & 30 & 82.27 & 7 & 17.73 \\
\hline Overall Response & & $\mathbf{8 1 . 8 3}$ & & $\mathbf{1 8 . 1 7}$ \\
\hline
\end{tabular}

Table 3. Reveals that out of all the 43 data collection tools issued to the respondents, the researcher recovered 35 yielding a unit response rate of $81.39 \%$. For the recovered tools, $82.27 \%$ of the items' response was valid. This study was considered to be a success as data was found to be sufficient for analysis since the overall response rate was $81.83 \%$ according to Babbie (1995) who considers $70 \%$ response rate and above to be very good.

\subsection{Descriptive analysis}

\subsubsection{Bank Customers Report for CRB}

The study sought to establish whether the targeted banks forward negative reports on their customers' history to CRB. The study established that majority of commercial banks in Kenya (94.3\%) forward negative credit histories of their customers to CRB with only $5.7 \%$ stating otherwise. The information that the commercial banks forward to CRB comprises of both positive and negative information concerning performance and non-performance status was found according to majority (30.3\%) of the respondents. The positive information constitutes a very small proportion of $(9.09 \%)$ comprising of diligent reports, outstanding running facilities among others. This in agreement with CBK (2010) that recommends sharing of information between financial institutions in respect of customer credit behavior since it has a positive economic impact.

\subsubsection{Approval of Loans Applied}

The study sought to establish the application of CRB reports in approving loans applied for by their customers. The respondents were to answer a set of questions, both closed-ended and openended questions whose findings are presented in Figure 1 and discussed, respectively as follows. 


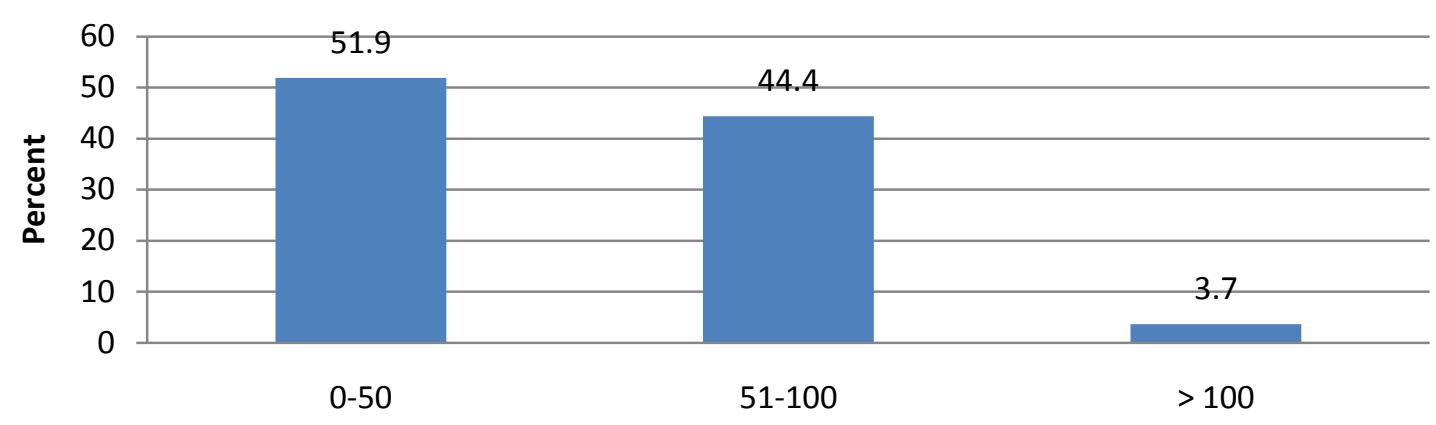

Approved Loan Applications

Figure 1: Number of Loan Applications Approved by Banks Based on CRB Report

The results in Figure 4.4 state that majority of banks (51.9\%) approves less than 50 loans and between 51-100 loans, and according to $44.4 \%$ with only $1 \%$ approving more than 100 loans per day. This shows that the banks are not putting enough emphasis on the CRB reports they inquire about the borrowers. This is in line with the findings of Epure and Lafuente (2012) who considers the information inquired from the CRB to be vital since it creates a better understanding and relationship between their customers with other lenders. This enables lenders to approve loan applications as well as offering targeted pricing to customers based on the level or risk involved with extending loans.

\subsubsection{Management of credit default risk}

Table 4: Use of Collateral to Manage Credit Risk

\begin{tabular}{lll}
\hline Loans & Frequency & Percent \\
\hline Used & 32 & 91.4 \\
Not used & 3 & 8.6 \\
\hline Total & $\mathbf{3 5}$ & $\mathbf{1 0 0}$ \\
\hline
\end{tabular}

The study revealed that $91.4 \%$ of the banks use collateral as the common credit risk mitigation technique. This is in agreement with Berger and Udell (2002) who postulate that risk management entails use of included collateral, loan securitization and covenants by banks especially in developing economies.

Table 5: Use of Guarantees to Manage Credit Risk

\begin{tabular}{lll}
\hline Loans & Frequency & Percent \\
\hline Used & 23 & 65.7 \\
Not used & 12 & 34.3 \\
\hline Total & $\mathbf{3 5}$ & $\mathbf{1 0 0}$ \\
\hline
\end{tabular}

The inference is that the majority of debtors use guarantees as their collateral because of lack of stable sources of income according to $65.7 \%$ of the respondents. The findings are consistent with study by Gieseche, (2004) who alleged that the banking sector has come of age in most countries, but nonetheless, these banks are not devoid of their customary problems. For instance, the banks can be faulted on not creating sufficient awareness to loan borrowers. 
Table 6: Use of Netting off of Loans to Manage Credit

\begin{tabular}{lll}
\hline Loans & Frequency & Percent \\
\hline Used & 32 & 91.4 \\
Not used & 3 & 8.6 \\
\hline Total & $\mathbf{3 5}$ & $\mathbf{1 0 0}$ \\
\hline
\end{tabular}

The credit officers accessed in the study stated that netting off loans is commonly used by commercial banks in Kenya to manage credit according to majority (91.4\%) with only $8.6 \%$ in dispute.

\subsubsection{Perceived Effectiveness of CRB in Risk Management}

The study as displayed in Table 7 and 8 indicate the respondents' perceptions on CRB effectiveness in reducing credit risks and instilling the culture of financial discipline respectively.

Table 7: Perceived Credit Risks Reduction

\begin{tabular}{lll}
\hline Credit risks status & Frequency & Percent \\
\hline Reduced & 31 & 96.9 \\
Not reduced & 1 & 3.1 \\
\hline Total & $\mathbf{3 4}$ & $\mathbf{1 0 0}$ \\
\hline
\end{tabular}

According to majority of the respondents (96.9\%), CRBs were perceived to be effective in reducing credit risks for the targeted banks while only $3.1 \%$ were of the opinion that CRBs were not effective in reducing credit risk. This result confirms those of Rukwaro(2001) who considers CRB to enable commercial banks reduce credit risks by lending more to better and not risky clients as well as determining better the bad loans that they need to cover expected losses of credit to good payers. In addition to that, they also argue that CRBs reduce the borrowing cost by forcing creditors to be more competitive for good borrowers. The study also confirms Kithinji (2010) who considers CBR to insure financial institutions against limited institutional capacity, inappropriate credit policies, volatile interest rates, poor management, inappropriate laws, low capital and liquidity levels, direct lending, massive licensing of banks, poor loan underwriting, laxity in credit assessment, poor lending practices, government interference and inadequate supervision by the central bank.

Table 8: Perceived Culture of Financial Discipline among Customers

\begin{tabular}{lll}
\hline Financial Discipline & Frequency & Percent \\
\hline Instilled & 33 & 94.3 \\
Not instilled & 2 & 5.7 \\
\hline Total & $\mathbf{3 5}$ & $\mathbf{1 0 0}$ \\
\hline
\end{tabular}

The research found out that majority (94.3\%) of the respondents considers the CRBs to have instilled some financial disciplines to targeted banks customers. This is results confirms those of Pagano and Japelli (1993) who postulates that moral hazard entails the risk in which a party to a 
transaction provides misleading information about its assets, liabilities or credit capacity, or has an incentive to take unusual risks in a desperate attempt to earn a profit before the contract settles.

\subsection{Correlation Analysis}

The researcher used Karl Pearson Correlation analysis to test the relationships between Credit Default Rate (CDR) and the roles of CRB in Risk Identification (RI). The nature of the relationship was determined by the coefficient of correlation while the significance of the relationship at 5\% levels of significance is explained by the p-value as presented in Table 9 .

Table 9: Karl Pearson Correlation of role of CRB and the CDR

\begin{tabular}{llll}
\hline & & CDR & RI \\
\hline \multirow{2}{*}{ Karl Pearson Correlation (r) } & CDR & 1 & 0.625 \\
& RI & 0.625 & 1 \\
\hline \multirow{2}{*}{$\boldsymbol{p}$-value } & CDR &. & 0.1 \\
& RI & 0.00 &. \\
\hline
\end{tabular}

The results as indicated in Table 9 above, the relationship between the Credit Default Rate (CDR) and Risk Identification (RI) the coefficient of correlation was $r(35)=0.625$, pvalue $=0.000<0.05$. This implies that the variables have a strong positive relationship that is a significant at $5 \%$ levels of significance.

\subsection{Regression Analysis}

The researcher conducted further inferential statistical test using regression analysis so as explain the influence of Risk Identification (RI) on Credit Default Rate (CDR). First the data was tested to determine its suitability for regression analysis as explained by the ANOVA in Table 10. Model summary in Table 11 explains the combined influence of the determining variables on the dependent. Then the regression coefficients in Table 12 were used to construct the multiple regression models as well as displaying the p-values for testing the significance of the variables influence at $95 \%$ levels of confidence.

Table 10: Regression ANOVA

\begin{tabular}{|c|c|c|c|c|c|c|}
\hline$\overline{\text { Model }}$ & & $\longdiv { \text { Sum of Squares } }$ & $\overline{\mathrm{Df}}$ & Mean Square & $\mathrm{F}$ & Sig. \\
\hline \multirow{3}{*}{1} & Regression & 955.093 & 1 & 955.093 & 4.455 & $.002^{\mathrm{b}}$ \\
\hline & Residual & 7074.749 & 33 & 214.386 & & \\
\hline & Total & 8029.841 & 34 & & & \\
\hline
\end{tabular}

a. Dependent Variable: CRD

b. Predictors: (Constant), RI

Since the $\mathrm{p}$-value $=0.002<0.05$ as displayed in the Regression ANOVA, this implies that regression analysis at $5 \%$ levels of significance is applicable for the study. 
Table 11: Model Summary

\begin{tabular}{lllll}
\hline $\mathrm{R}$ & $\mathrm{R}$ Square & $\begin{array}{l}\text { Adjusted } \mathrm{R} \\
\text { Square }\end{array}$ & $\begin{array}{l}\text { Std. Error of the } \\
\text { Estimate }\end{array}$ & Durbin-Watson \\
\hline $.0 .657 \mathrm{a}$ & 0.432 & 0.423 & 0.79 & 1.731 \\
\hline
\end{tabular}

a Predictors: (Constant) , RI

b Dependent Variable: CDR

According to R-Square value $=0.423$ as presented in Table 11, the combined effect of Risk Identification (RI), Credit Repayment (CR), Credit Access (CA), Reduction of Moral Hazard $(\mathrm{RMH})$, Credit Information Evaluation (ET) recorded a total of $42.3 \%$ of the dependent variable that is Credit Default Rate (CDR) with the rest proportion explained by extraneous variables as well as the error term.

Table 12: Regression Coefficients

\begin{tabular}{lll} 
& Unstandardized Coefficients $(\mathbf{B})$ & $\boldsymbol{p}$-value \\
\hline (Constant) & -0.256 & 0.708 \\
RI & 0.657 & 0.025 \\
\hline
\end{tabular}

a Dependent Variable: CDR

The regression coefficients as displayed in Table 12 above were used to construct the regression model below. From the model below, the constant value was found to be -0.256 .

CDR = - $0.256+0.657$ RI

The Risk Identification and Credit Default Rate recorded a coefficient of regression of 0.657, pvalue $=0.025<0.05$. This implies that the variables have a positive relationship that is significant at $5 \%$ levels of significance.

\subsection{Hypothesis testing}

Chi-Square Analysis on the Influence of CRB on Credit Default Rates. Further tests were conducted for confirmatory purposes using Chi-Square analysis. The results of the Pearson ChiSquare Values, degrees of freedom and p-value at $95 \%$ levels of confidence are presented in Table 4.34.

Table 13: Chi-Square Results

\begin{tabular}{llll}
\hline Determinants & Pearson Chi-Square & Degrees of Freedom & $\boldsymbol{p}$-value \\
\hline RI & 76.532 & 8 & 0.000 \\
\hline
\end{tabular}

As indicated in Table 4.34 above, the influence of Risk Identification on Credit Default Rates 2

yielded a $\chi(8, \mathrm{~N}=35)=76.532, \mathrm{p}=0.000<0.05$. This implies that its influence is a significant at $5 \%$ levels of significance.

\section{CONCLUSION}

The study aimed at establishing the role of CRB in influencing risk identification in mitigating credit risk default.To facilitate conclusions, the researcher conducted inferential statistical tests to verify the acceptance or rejection of the study hypotheses. The inferential statistics test that 
were conducted to test the influence of risk identification on credit default in commercial banks in Kenya that yielded a coefficient of correlation of $\mathrm{r}(35)=0.625$, p-value $=0.000<0.05$. The regression analysis yielded a coefficient of 0.657 , p-value $=0.025<0.05$. While the Chi Square yielded $\chi(8, \mathrm{~N}=35)=76.532, \mathrm{p}=0.000<0.05$. This implies that the null hypothesis as stated; $\mathrm{CRB}$ does not play a significant role in risk identification in mitigating against credit default in commercial banks in Kenya. This therefore informs the acceptance of the alternative hypothesis that states; CRB plays a significant role in risk identification in mitigating against credit default in commercial banks in Kenya. This facilitates the conclusion that CRB plays a significant role in risk identification in mitigating against credit default in commercial banks in Kenya at 5\% levels of significance. The study recommends that an open system needs to be enhanced to allow financial institutions as well as non-bank entities; retailers, wholesalers, telecom and utility companies access to credit history of borrowers to know which clients to serve and what differential price to charge to cover risks. To facilitate financial performance of commercial banks even more effectively, information access should be available at low or no cost. The regulator of the financial institutions that is the central bank should enact policies that guide the use of the credit reference bureau information by banks as well as the consumers. The researcher suggest the need for an intensive study to be conducted to assess the awareness levels, attitudes, benefits and challenges encountered by borrowers with regard to the of application of CRB reports as far as loan facilitation is concerned.

\section{REFERENCE}

[1] Ahmad, N. H. and Ariff, M. (2007). Multi-Country Study of Bank Credit Risk Determinants, International Journal of Banking and Finance, 5(1): 135-152.

[2] Ahmed, A. S., Takeda, C. and Shawn, T. (1998). Bank Loan Loss Provision: A Reexamination of Capital Management and Signaling Effects, Working Paper, Department of Accounting, Syracuse University, 1-37.

[3] Al-Khouri, R. (2011). Assessing the Risk and Performance of the GCC Banking Sector, International Journal of Finance and Economics, 65: 72-8.

[4] Allen, F., Santomero A., (1998). The Theory of Financial Intermediation. Journal of Banking and Finance and Public Management, 21: 1461-1485.

[5] Auronen, L. (2003). Asymmetric Information: Theory and Applications. Paper presented in the Seminar of Strategy and International Business as Helsinki University of Technology, May 21st 2003.

[6] Barron, J. M., \& Staten, M. (2003). The value of comprehensive credit reports: Lessons from the US experience. Credit reporting systems and the international economy, 8, 273-310.

[7] Berger, A. and Frame, S. (2005). Small business credit scoring and credit availability. The Journal of Banking and Finance

[8] Bizer, D.S. \& Peter, M. D.(1992).Sequential Banking.Journal of Political Economy, 100(1): 41-61.

[9] Brown, M., Tullio, J \& Marco P. (2007). "Information Sharing and Credit: Firm-Level Evidence from Transition Economies." Center for Studies in Economics and Finance Working Paper 178.by Financial Intermediaries: A dissertation presented in partial fulfillment of the Requirements for the Degree of Doctor of Philosophy in the Graduate School of the Ohio State University 2003

[10] CBK (2010). Kenya Licenses the First Credit Reference Bureau - Credit Reference Bureau Africa Limited (CRB Africa). Press release.

[11] Collins, N.J., \& Wanjau, K. (2011).The Effects of Interest Rate Spread on the Level of Non-Performing Assets: A Case of Commercial Banks in Kenya, International Journal of

Business and Public Management 1(1).

[12] Daniels, R. (2004). Financial Intermediation, Regulation and the Formal Microcredit Sector in South Africa. Development South Africa, 21(4): 831-49.

[13] Derban, W.K., Binner, J.M. \& Mullineux, A. (2005).Loan repayment performance in community development finance institutions in the UK, Small Business Economics, 25: 319-32.

[14] Diamond, D., Rajan R., (2001). Liquidity risk, creation and financial fragility: A theory of banking. Journal of Political Economy, 2: 287-327. 
[15] Djankov S., McLiesh C., \& Shleifer A., (2005). Private Credit in 129 Countries, NBER Working Paper 11078 (Cambridge, Massachusetts: National Bureau for Economic Research).

[16] Donaldson, T.H. (1994). Credit Control in Boom and Recession, The Macmillan Press: Basingstoke.

[17] Drehman, M., Sorensen, S. \& Stringa, M. (2008). The Integrated Impact of Credit and Interest Rate Risk on Banks: An Economic Value and Capital Adequacy Perspective, Bank of England Working Paper No.339. Economic Research Consortium, Research Paper 106.

[18]Epure, M. \& Lafuente, I. (2012).Monitoring Bank Performance in the Presence of Risk, Barcelona GSE Working Paper Series No.61.

[19] Ferretti, F.F. (2006). Re-thinking the regulatory environment of credit reporting: Could legislation stem privacy and discrimination concerns? Journal of Financial Regulation and Compliance, 14 (3): $254-272$.

[20]Fuser, K., Gleiner, W. \& Meier, G. (1999). Risk management - Erfahrungenaus der Praxis, Der Betrieb, 52(15): 753-758.

[21] Gaitho, N. (2010). The role of credit reference bureau on credit access, a survey of commercial banks in Kenya. Unpublished MBA Project. University of Nairobi.

[22] Gieseche, K. (2004). Credit Risk Modeling and Valuation: An Introduction, Credit Risk: Models and Management, Vol.2, Cornell University, London.

[23] Greuning, H., \& Bratanovic, S.B. (2003), Analyzing and Managing Banking Risk: A Framework for Assessing Corporate Governance and Financial Risk, 2nd ed., The World Bank, Washington, DC.

[24] Heffernan, S. (1996).Modern Banking in Theory and Practice, Wiley: New York.

[25] Hoff, K., \& Joseph S. (1998). "Moneylenders and Bankers: Price-Increasing Subsidies in a Monopolistically Competitive Market." Journal of Development Economics 55: 485-518.

[26] Holden, J.M. (1985). The Law and Practice of Banking (Volume 2): Securities for Bankers' Advances.

[27] Hoque, M, Z. (2009). Flawed working capital loan policy and loan default: Evidences from Bangladesh, Journal of Accounting, Business and Management, 11(2): 202- 213.

[28] IAIS - International Association of Insurance Supervisors (2003), paper on Credit Risk Transfer between Insurance, Banking and Other Financial Sectors, March. Italy Research Department,

[29] Rome.Jappelli, T., \& Marco, P. (1993).Information sharing in credit markets, Journal of Finance.45 (2).1719.

[30] Jappelli, T.\& Marco P. (1993). Information Sharing in Credit Markets. Journal of Finance.48 (5):16931718.

[31] Jappelli, T.\& Marco P. (2000). "Information Sharing in Credit Markets: A Survey." University of Salerno: CSEF Working Paper no. 36.

[32] Jappelli, T. and Pagano, M. (2002): Information sharing, lending and defaults: Cross-country evidence, Journal of Banking \& Finance, 5(3): 19-27.

[33] Jappelli, Tullio, and Marco Pagano, 'information Sharing, Lending and Defaults: Cross-CountryEvidence', (2002) 26 (10) (October) Journal of Banking and Finance 2017-2045.

[34] Kallberg, J. G., \& Udell, G. F. (2003).The value of private sector credit information, Journal of Banking and Finance and Institutional Economics, 2(1): 45-65

[35] Kargi, H. S. (2011). Credit Risk and the Performance of Nigerian Banks, Ahmadu Bello University, Zaria.

[36] Kaynak, E.\&Harcar, T. (2001).Consumers' Attitudes and Intentions Toward Credit Card Usage in an Advanced Developing Country. Journal of Financial Services Marketing, 6(1): 24-39.

[37] Kevin, G. \& Tiffany, G. (2010). Forecasting non-performing loans in Barbados: Business, Finance \& Economics in Emerging Economies vol. 5.

[38] Kithinji, A. and Waweru, N. M. (2007). Merger restructuring and financial performance of commercial banks in Kenya: Economic, Management and Financial Markets Journal.

[39] Kithinji, A. M. (2010). Credit Risk Management and Profitability of Commercial Banks in Kenya, School of Business, University of Nairobi, Nairobi.

[40]Leonard, K. J. (1995). The development of credit scoring quality measures for consumer credit applications. International Journal of Quality \& Reliability Management, 12(4): 79 - 8558

[41] McIntosh, C. \& Bruce, W. (2005).Competition and Microfinance. Journal of Development Economics, 78: 271-98.

[42] Mugenda, Olive M. and Abel G. Mugenda, (2003) Research Methods: Quantitative \& Qualitative Approaches.Nairobi.Acts Press.

[43] Mumi, S.M. (2010). The Impact of Credit Reference Bureau in Financial Institutions. School of Business, University of Nairobi, Nairobi. 
[44] Nalukenge, I.K. (2003). Impact of Lending Relationships on Transaction Costs Incurred by Financial Intermediaries: A dissertation presented in partial fulfillment of the Requirements for The Degree of Doctor of Philosophy in the Graduate School of The Ohio State University 2003.

[45] Nganga, M.M. (2011). A study on stakeholder perception of credit reference bureau service in Kenya Credit Market. Unpublished MBA Project. University of Nairobi.

[46] Ngugi, R.W. (2001). An Empirical Analysis of Interest Rate Spread in Kenya.African Economic Research Consortium, Research Paper 106.

[47] Sinare, E.H. (2008). Credit Reference Bureau in Tanzania and Better Environment for Lenders and Borrowers. World Service Group Sullivan.

[48] Stieglitz, J. E., \& Weiss, A. (1981).Credit rationing in markets with imperfect information. The American economic review, 71(3), 393-410. 